\title{
THE BEHAVIOR OF WASTE DISPOSAL INTO RIVER AMONG COMMUNITY IN SUNGAI KAKAP SUBDISTRICT WEST KALIMANTAN
}

\author{
Reni Oktaliana ${ }^{1}$, Ahmad $^{2}$, Chatarina Muryani ${ }^{3}$ \\ ${ }^{1}$ Geography Education Study Program, Universitas Sebelas Maret, Indonesia \\ ${ }^{23}$ Thesis Advisor, Universitas Sebelas Maret, Indonesia \\ Email: renioktaliana94@gmail.com
}

\begin{abstract}
This research was carried out in the Sungai Kakap Subdistrict, Kubu Raya Regency of West Kalimantan. The waste problem is one of the issues exists in Indonesia. Waste affects the cleanliness of the environment and the surrounding. Disposing waste into a river is an example of irresponsible practices. Nowadays, the river has become a practical and free of charge location to dispose of waste. People tend to develop waste disposal into a river as a habit without caring for the negative impacts of their behavior. The purposes of this research were to determine the behavior of the community in disposing of waste into the river. The results of this current study indicated that around $70 \%$ of the community members utilized the water for their daily needs, such as bathing, cleaning and also as the clean water resources. The score of the behavior of the community regarding waste disposal into the river was 1.570. This was in a "bad" category. People's knowledge of their environment influenced their behavior in disposing of waste into the river. Knowledge about the environment affects people's behavior in disposing of waste into the river. Ecological awareness influenced community behavior in disposing of waste into rivers. In general, the people in the study area realized that disposing waste into rivers was irresponsible and brought a negative impact on the environment, but the habit of throwing waste into rivers was hard to change, it was like a tradition which was not easy to abandon.
\end{abstract}

Keywords: Community behavior, environmental knowledge, ecological awareness.

\section{A. INTRODUCTION}

A waste-related problem is an issue encountered by Indonesia. It causes several problems, one of which is the cleanliness of the environment. Unfortunately, it seems that society tends to ignore the environment. This is evidenced by irresponsible practices of the community members who dispose of waste into the river and low awareness of the environment. The river has become practical and free of charge to dispose of waste. This behavior endangers people and the environment since it brings some negative impacts. Behavior is a person's response to stimuli from outside. The control of behavior directly affects the intention to implement it and also the intention is considered to have influences on behavior (Soekidjo Notoatmodjo, 2003). Attitude and behavior are influencing one another. Attitude is someone's responses or reactions toward stimuli. This response 
can be both positive and negative. A positive attitude is said to correlate with positive behavior. So, there is a correlation between attitude and community behavior.

The increase in the population will automatically lead to several complex issues. One of the common issues that needs to be addressed seriously is the garbage disposal problem. This requires a serious handling strategy to avoid a bigger impact. According to Law No 18 the Year 2008 (Undang-Undang Republik Indonesia Nomor 18 Tahun 2008), the large population of Indonesia with high growth rates increases the volume of waste. The behavior of the community regarding garbage disposal is still in a bad category. The community awareness of the environment is still low, indicated from the practices of disposing of the garbage into the river. In addition, the community also burns the garbage.

The community has the notion that disposing waste into the tidal river is one of the appropriate solutions in handling waste, disposing waste at any form into the river is not a solution. This is exacerbated by the lack of landfills, lack of public awareness in disposing of waste, and lack of community understanding of waste which cause a decrease in environmental quality that has a negative impact on the community (Tobing.I.S,2005). The existence of garbage bins will reduce community waste disposal into rivers. In addition, imposing strict sanctions on waste disposal into rivers and providing examples of environmental attitudes from community leaders can also be a way to change community behavior. (Dimopoulos, 2009). Stated that the help of exemplary figures will be one way to create a caring attitude towards the environment.

Improving environmental education can be realized with environmental education. Environmental education in the community can be done by empowering specific communities in waste management. Environmental Education to enhance Environmental Literacy to build knowledge, awareness, and the ability to think critically about the environment so as to facilitate the active development of a sustainable environment (Lin, E,2014). Environmental problems raised by the community related to environmental education that are obtained early can change the character and habits that can be opposed to the environment (Chun, 2012). 


\section{B. MATERIALS AND METHODS}

This research was conducted in Sungai Kakap Subdistrict, Kubu Raya Regency of West Kalimantan in March 2019. The population of this research was all people who lived alongside the river in Sungai Kakap Subdistrict. The communities from three selected villages were chosen as the sample of the research. The villages were Sungai
Kakap, Sungai Belidak, and Punggur Kecil. The sampling technique used was purposive sampling. Purposive sampling is a sampling technique where a researcher sets certain criteria for the sample to be involved in his study (Sugiyono, 2016). The location of the research is presented in the following figure.

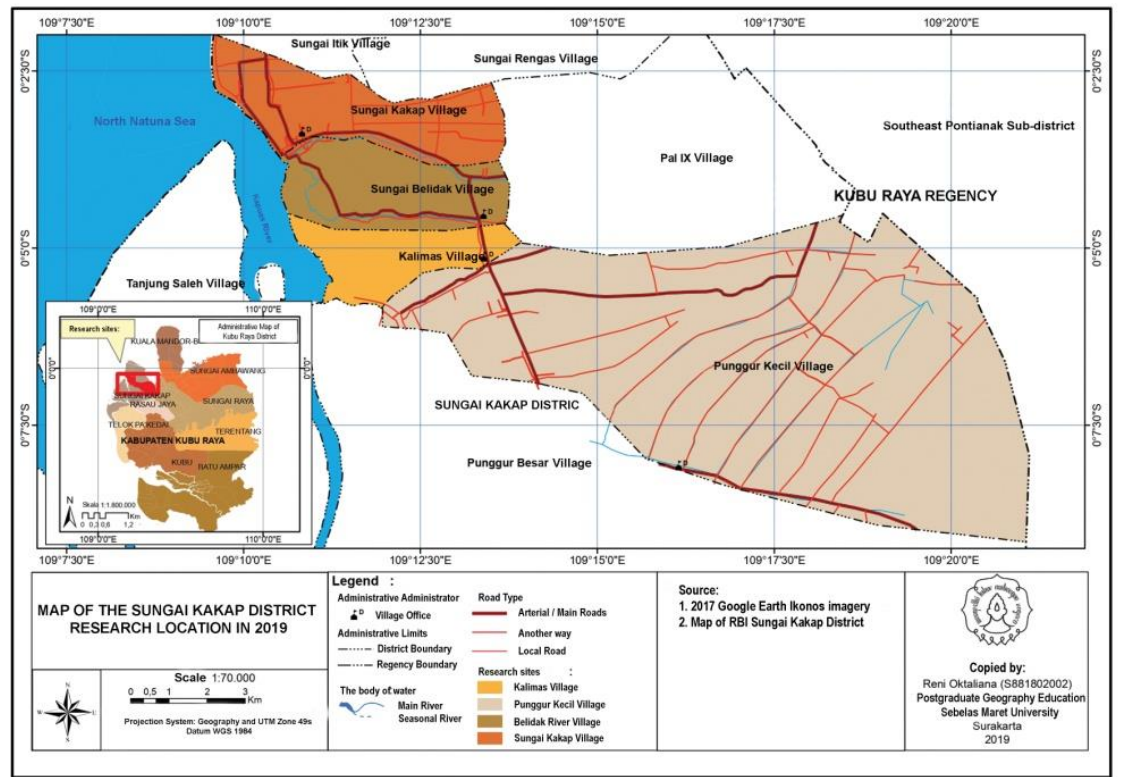

Figure 1. The Map of the Research Site in Sungai Kakap Subdistrict

Attitude measurement was performed by using the Likert $\mathrm{R}$ attitude scale with 5 alternative answers or responses to questions, ranging from strongly agree to strongly disagree. The rating of each question moved from 1-4, the lowest value was 0 and the highest value was 4 . If the question was positive, the score was 4 , conversely, if the question was negative, the score was 0 . The high score obtained by someone indicated a positive attitude toward the object, and vice versa (Bimo Walgito, 2001).

To analyze the community behavior regarding waste disposal into the river, a quantitative analysis was done. This was done by analyzing the respondents' responses to the questionnaire by using the following formula: 
The Number of Respondents answers

Number of Respondents

Scoring was used to determine the score of the respondents and to categorize the responses into several classifications, which were bad, moderate, and good categories. The following table shows the criteria of the indicator.

Table 1. Criteria for positive indicator

\begin{tabular}{ccc}
\hline No & Criteria & Score \\
\hline 1 & Always & 4 \\
2 & Often & 3 \\
3 & Rarely & 2 \\
4 & Never & 1 \\
\hline
\end{tabular}

The highest score for the positive indicator was 4, and the lowest score was 1 . While for the negative indicator, the following criteria were applied.

Table 2. Criteria for negative indicator

\begin{tabular}{ccc}
\hline No & Criteria & Score \\
\hline 1 & Always & 1 \\
2 & Often & 2 \\
3 & Rarely & 3 \\
4 & Never & 4 \\
\hline
\end{tabular}

Maximum Score $=$ Number of Respondents $\mathrm{x}$ Large Score Criteria $\mathrm{x}$ Number of Indicators $=90 \times 4 \times 9=3.240$

Minimum Score $=$ Number of Respondents $\mathrm{x}$ Small Score Criteria $\mathrm{x}$ Number of Indicators $=90 \times 1 \times 9=810$

Table 3. Behavior Category

\begin{tabular}{ccc}
\hline No & Criteria & Score \\
\hline 1 & Bad & $810-1.620$ \\
2 & Moderate & $1.621-2.430$ \\
3 & Good & $2.431-3.240$ \\
\hline
\end{tabular}




\section{RESULTS AND DISCUSSION}

Human behavior is all human activities, both those that are directly observable and those that cannot be observed by outsiders (Soekidjo Notoatmodjo, 2003). Referring to the above explanation, this research seeks to understand the behavior of the community living alongside the river. Starting from how the community uses the river for their lives and their behavior in dealing with the waste problems. Based on the results of the interview, 63 people or around $70 \%$ of the community utilized the water for their daily need, it means the river holds a crucial role for the community since they used it for their daily activity such as washing, bathing, and as a source of clean water. The following picture show how people use the river for their daily needs.

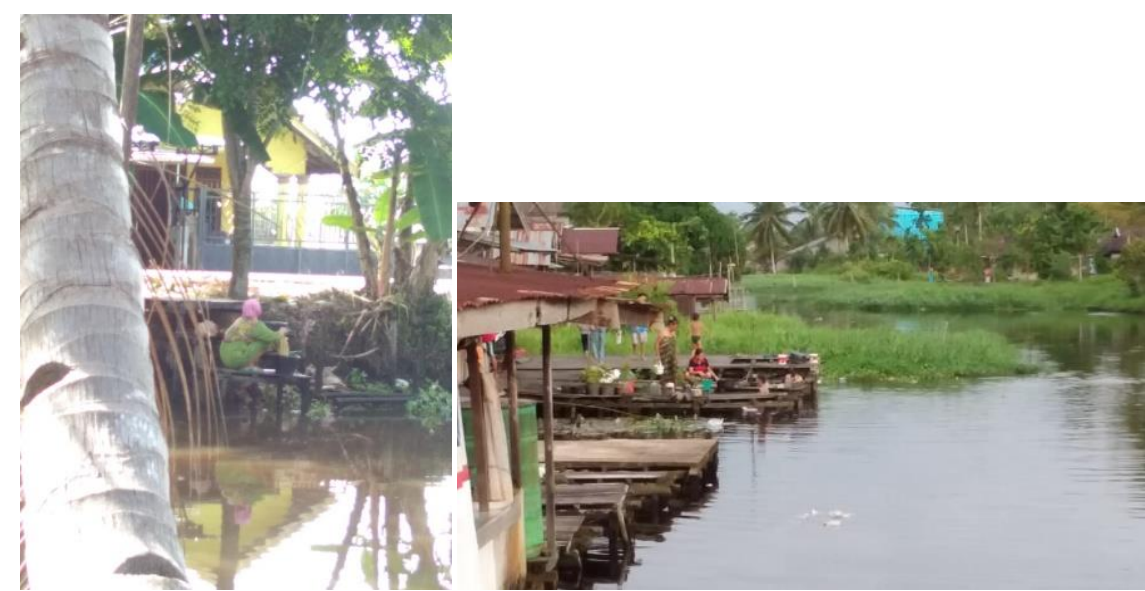

(a) Low tide (b) High tide

Figure 2. People activities in utilizing the river for their daily needs

The good behavior of the community will result in positive impacts on the environment, and vice versa. The behavior of the community in disposing of waste into the river is presented in the following table. 
Table 4. Community behavior regarding waste disposal (\%)

\begin{tabular}{|c|c|c|c|c|c|c|c|c|c|c|}
\hline \multirow{2}{*}{ No } & \multirow{2}{*}{ Indicator } & \multicolumn{2}{|c|}{ Always } & \multicolumn{2}{|c|}{ Often } & \multicolumn{2}{|c|}{ Rarely } & \multicolumn{2}{|c|}{ Never } & \multirow{2}{*}{$\begin{array}{c}\text { Total } \\
\%\end{array}$} \\
\hline & & Total & $\%$ & Total & $\%$ & Total & $\%$ & Total & $\%$ & \\
\hline 1 & Disposing waste/garbage in its place & 25 & 27,8 & 13 & 14,4 & 45 & 50 & 7 & 7,8 & 100 \\
\hline 2 & Disposing waste/garbage into the river & 73 & 81 & 17 & 18,9 & 7 & 7,8 & 3 & 3,33 & 100 \\
\hline 3 & $\begin{array}{l}\text { Waste disposal was done in the } \\
\text { morning or during the day }\end{array}$ & 47 & 52,22 & 16 & 17,8 & 19 & 21 & 8 & 8,9 & 100 \\
\hline 4 & $\begin{array}{l}\text { Disposing waste into the river every } \\
\text { day }\end{array}$ & 71 & 78,9 & 11 & 12 & 6 & 6,7 & 2 & 2,2 & 100 \\
\hline 5 & $\begin{array}{l}\text { Never disposing the waste into the } \\
\text { river }\end{array}$ & 23 & 25,56 & 17 & 18,9 & 37 & 41 & 13 & 14,44 & 99,9 \\
\hline 6 & Throwing garbage into the river & 37 & 41 & 22 & 24,44 & 18 & 20 & 13 & 14,44 & 99,88 \\
\hline 7 & $\begin{array}{l}\text { Selecting the waste before disposing it } \\
\text { into the river }\end{array}$ & 12 & 13,33 & 11 & 12 & 47 & 52 & 20 & 22,22 & 99,55 \\
\hline 8 & $\begin{array}{l}\text { All waste from daily activities was } \\
\text { disposed into the river }\end{array}$ & 51 & 56,67 & 32 & 35,56 & 6 & 6,7 & 3 & 3,33 & 100 \\
\hline 9 & $\begin{array}{l}\text { Selecting the waste before disposing of } \\
\text { it in the trash }\end{array}$ & 7 & 7,8 & 5 & 5,56 & 29 & 32,22 & 49 & 54,44 & 100 \\
\hline & Total & 346 & 384.28 & 144 & 159,56 & 214 & 237,42 & 118 & 131,1 & 100 \\
\hline
\end{tabular}


The results of the questionnaire revealed that there were 73 people (which was the highest of the criteria) who disposed the garbage into the river this was equivalent to $81 \%$ of the total members of the society. This indicated that people did not care about their environment. Moreover, their habit could be categorized as a bad habit in dealing with the garbage problem. It is also informed that the lowest of the behavior indicator was on selecting the waste before disposing it into the trash, done by 7 people or equivalent to $7.8 \%$ of the total members of the society. This result tells that the community did not separate the waste before disposing it into the river. They directly threw the waste into the river. People who have a low perception of the environment and still bring up the behavior of throwing garbage in the river show that the educational goals have not been achieved. Communities that surround the environment will have a high perception of the environment and participate in protecting the environment by throwing garbage in the trash (Teksoz, G, Sahin, E., \& Tekkaya, 2012).

The negative trait was also shown in the behavior of disposing of waste into the river every day. Thi s was done by 71 people. The score for this behavior was 1.570 . the following graph presents the score of the community behavior in disposing waste into the river.

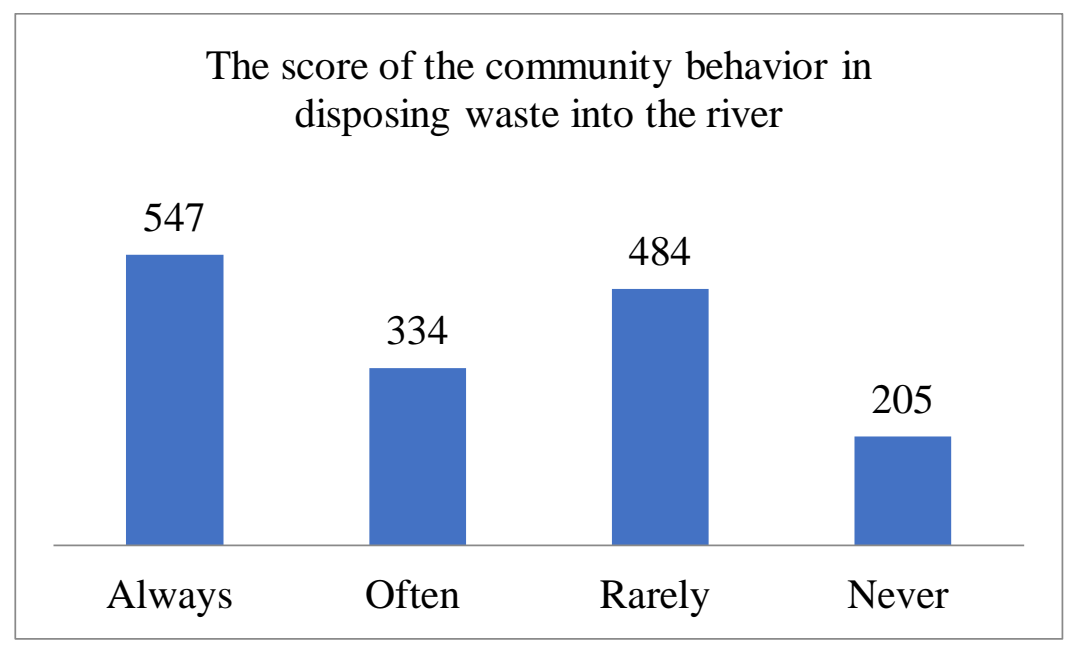

Figure 3. The graph of the score of the community behavior in disposing of waste into the river

The highest behavior score of the community in disposing of waste into the river was 547 with "always" responses. This means that the number 
of those who disposed of waste into the river was higher than those who did not, with the lowest score of 205. While those who provided "often" answers were scored 334, this indicated that the community disposed of the waste into the river often. For the "rarely" responses were scored 484, which means the community rarely disposed of waste into the river. The score of the community behavior in disposing of waste into the river was 1.570 . This was included in a bad category with a score ranging from 1.621-2.430.

Environmental care influences people's behavior about addressing environmental problems. Behavior of caring for the environment is influenced by factors of knowledge and education, personality and responsibility towards the environment (Gifford \& Nilsson, 2014). Environmental education is a part of natural science education, the aim of which is to increase scientific literacy (Liu, 2009).

\section{CONCLUSIONS}

Around $81 \%$ of the community members disposed of waste into the river with a score of 1.570 . This is included in the bad category. The more respondents provided the "always" response, the worse their behavior regarding waste disposal into the river.
Knowledge about the environment influences the behavior of the community in disposing of waste into the river, good environmental knowledge has an impact on good community behavior and is responsible for the environment.

\section{E. ACKNOWLEDGMENTS}

Thank you to our parents and the community in the Sungai Kakap Subdistrict who had provided good access for us to carry out this research. Thank you, Dr. Ahmad, M.Pd and Prof. Dr. Chatarina Muryani, M.Si as the thesis advisors at the Geography Education Study Program of Universitas Sebelas Maret.

\section{F. REFERENCES}

Bimo Walgito. (2001). Psikologi Sosial. Jakarta: Andi offset.

Chun, M.H., Sulaiman,W.N.A.,\& Samah, M. A. . (2012). A Case Study on Public Participation for the Conservation of a Tropical Urban River. Pol J. Environmental Study, 21 (4), 82.

Dimopoulos,I.D.,Paraskevopoulos,S., \& Pantis, J. . (2009). Planning Educational Activities and Teaching Strategies on Constructing a Conservation Educational Module. International Journal of Environmental and Science Education, 4 (4), 351.

Gifford, R., \& Nilsson, A. (2014). Personal and social factors that 
influence pro-environmental concern and behaviour: A review. International Journal of Psychology, 49(3), 141-157. https://doi.org/10.1002/ijop.1203 4

Lin, E., \& S. Q. (2014). xploring Individual and School-Related Factors and Environmental Literacy: Comparing U.S. and Canada Using PISA 2006. Nternational Journal of Science and Mathematics Education, 12,73-97.

Liu, X. (2009). Beyond science literacy: Science and the public. International Journal of Environmental and Science Education, 4(3), 301-311.

Soekidjo Notoatmodjo. (2003). Pendidikan dan Perilaku
Kesehatan. Jakarta: Rineka Cipta.

Sugiyono. (2016). Metode Penelitian Kuantitatif, Kualitatif, dan R\&D. Bandung: Alfabeta.

Teksoz, G., Sahin, E., \& Tekkaya, O. . (2012). Modelling Environmental Literacy of University Students. Journal of Science Education Technology, 21:157-166.

Tobing., I., S., L. (2005). Dampak Sampah Terhadap Kesehatan Lingkungan dan Manusia. Jakarta: Kerjasama Universitas Nasional dan DIKMENTI DKI.

Undang-Undang Republik Indonesia Nomor 18 Tahun 2018. (2008). Undang-undang Republik Indonesia Nomor 18 Tahun 2008 Tentang Pengelolaan Sampah. 112. 